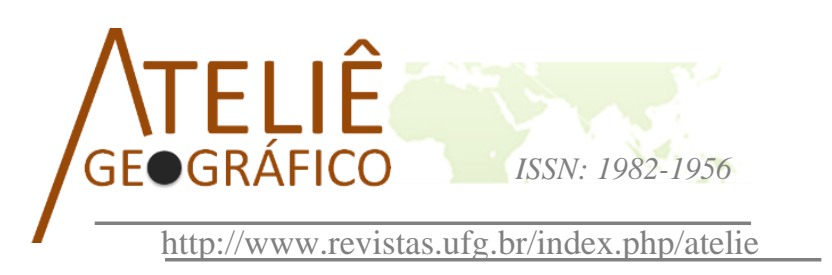

\title{
A gentrificação não é um efeito colateral: complexificando o conceito para revelar objetivos escusos
}

\author{
La gentrificación no es un efecto secundario: complejar el \\ concepto para revelar objetivos ocultos
}

\section{Gentrification is not a collateral effect: complexifying the concept to reveal hidden goals}

\author{
Alvaro Ferreira \\ Pontifícia Universidade Católica do Rio de Janeiro (PUC-Rio) \\ Universidade do Estado do Rio de Janeiro \\ alvaro_ferreira@puc-rio.br
}

\begin{abstract}
Resumo
Inúmeros projetos de "revitalização" ou de "renovação urbana" têm sido implementados em inúmeras cidades do mundo. Os resultados têm gerado o que os pesquisadores denominaram de gentrificação. Entretanto, há um intenso debate acerca da utilização desse termo, alguns criticando o seu uso indiscriminado e outros acreditando ser necessário complexificar o conceito. Este artigo se propõe a rediscutir as definições e o uso da expressão gentrificação. Além disso, partimos da hipótese de que a gentrificação não é um efeito colateral ou uma catástrofe natural; a gentrificação é planejada.
\end{abstract}

Palavras-chave: Gentrificação. Metropolização. Revitalização. Espoliação. Turistificação

\section{Resumen}

Se han implementado innumerables proyectos de "revitalización" o "renovación urbana" en innumerables ciudades de todo el mundo. Los resultados han generado lo que los investigadores llamaron gentrificación. Sin embargo, existe un intenso debate sobre el uso de este término, algunos critican su uso indiscriminado y otros creen que es necesario complejizar el concepto. Este artículo tiene como objetivo volver a discutir las definiciones y el uso del término gentrificación. Además, partimos de la hipótesis de que la gentrificación no es un efecto secundario ni una catástrofe natural; la gentrificación es una estrategia planificada.

Palabras clave: Gentrificación. Metropolización. Revitalización. Expoliación. Turistificación 


\begin{abstract}
Countless urban revitalization or urban renewal projects have been implemented in innumerous cities around the world. The results cause what social scientists call gentrification. There is, however, a great debate about the use of this term. While some criticize its indiscriminate use, others believe it is necessary to make the concept a little more complex. This paper intends to discuss the definitions and the use of the gentrification term. Furthermore, our hypothesis consists that the gentrification is not a collateral effect or a natural catastrophe; it is planned.

Keywords: Gentrification. Metropolization. Revitalization. Despoliation. Touristification
\end{abstract}

\title{
Introdução... ou apresentando um problema
}

Há um intenso debate acerca do uso indiscriminado do termo gentrificação. Alguns autores acreditam que tal noção apresenta certos limites de utilização e que tem havido pouco cuidado e rigor em sua apropriação. Esses pesquisadores afirmam que se tem designado por gentrificação, basicamente, qualquer processo de mudança ocorrida em um bairro ou cidade.

Acreditamos ser necessário retomar o debate para que repensemos o conceito de gentrificação e nos aproximemos da realidade vivida pelos citadinos. Não devemos "engessar" definições, seja no tempo ou no espaço, portanto este artigo procura desenvolver uma reflexão que propõe a complexificação do conceito de gentrificação.

Partimos da hipótese de que a gentrificação não é, como acreditam alguns (ou querem nos fazer acreditar), um efeito colateral ou uma catástrofe natural; a gentrificação é planejada.

\section{Complexificando o conceito de gentrificação}

A dinâmica do processo de metropolização tem contribuído para a transformação do mercado do solo urbano, que passa por uma valorização assustadora, elevando os preços a números nunca antes imaginados. Torna-se clara, então, a importância da propriedade privada do solo como condição indispensável à produção imobiliária formal (LENCIONI, 2013). Tal elevação de preços faz com que as construtoras busquem áreas mais distantes para construção, incorporando novas áreas à lógica de mercado da metrópole, o que acaba por estender a área urbana indefinidamente. Fato que obriga os moradores a realizarem grandes deslocamentos diariamente.

As áreas de expansão e de investimentos nas cidades acabam sendo definidas pelos proprietários fundiários, pelas construtoras e pelos promotores imobiliários. Esse movimento fez a geógrafa Sandra Lencioni (2013, p. 29) afirmar que as centralidades

são produzidas muito menos pelas necessidades da cidade desempenhar as funções de comércio e de serviços, e, muito mais, devido às necessidades da reprodução do capital do setor imobiliário. Em suma, a multicentralidade não é um produto das funções urbanas, mas dos investimentos imobiliários. 
O processo de metropolização tem, simultaneamente, levado ao adensamento de determinadas áreas, ao espraiamento da metrópole e às operações urbanas de renovação urbana ou de revitalizações (como preferem alguns), que acabam por gerar forte gentrificação.

Grande parte dos projetos denominados de revitalização, que alteram as características do lugar criando novas fronteiras urbanas, acaba levando a processos de gentrificação, que de certa forma não deixa de ser uma forma de espoliação. Cabe, aqui, fazer um breve esclarecimento acerca da expressão gentrificação, que nasce do termo inglês gentrification, cunhado por Ruth Glass (1963), para esclarecer o repovoamento, por famílias de classe média, que vinha acontecendo em bairros desvalorizados de Londres na década de 1960, levando à transformação do perfil dos moradores. Atualmente, usa-se a expressão gentrificação como resultado dos projetos de "revitalização", de "recuperação" ou de "requalificação" (seja lá qual for a expressão utilizada) de locais degradados a partir de iniciativas públicas e privadas. Trata-se de um fenômeno de natureza multidimensional, que reúne modernização e deslocamento; ou seja, referimo-nos à modernização e à melhoria de antigos prédios associadas ao desenvolvimento de atividades culturais em determinadas áreas residenciais, levando ao deslocamento dos antigos moradores. A questão é que após o investimento em infraestrutura, há uma maior valorização do lugar; assim, observamos que os antigos moradores não resistem ao encarecimento do local, tendo que buscar outra área com custo de vida mais baixo. Se, inicialmente, a gentrificação ligava-se ao mercado residencial, o enobrecimento dos lugares acabou incorporando áreas de lazer com complexos culturais voltados também para o turismo. Assim, o geógrafo belga Mathieu Van Criekingen (2007) define dois tipos de gentrificação - residencial e de consumo - que levam à produção glamourizada do espaço através da maior sofisticação dos ambientes. Evidentemente, há formas de gentrificação que mesclam as dimensões residencial e de consumo, como, por exemplo, Barcelona.

A mídia exerce importante papel ao promover esses locais, ajudando a criar um discurso hegemônico acerca do lugar, que contribui cada vez mais para a atração de consumidores. Os profissionais de publicidade contratados têm importante papel, visto que elaboram discursos que dão sustentação aos projetos propostos. Procuram incutir no imaginário social, inclusive até no dos mais despossuídos e excluídos do seu usufruto, que esses projetos trarão mais "qualidade de vida" aos habitantes.

Inicialmente quando se falava em gentrificação, tratava-se de referir-se a antigas áreas centrais degradadas que receberam investimentos públicos e privados, criando novos nichos de mercado para os negócios e para habitação. Entretanto, o conceito de gentrificação tem se tornado muito mais complexo e muito mais amplo.

É importante afirmarmos que as conceituações são construídas a partir do surgimento do processo em questão, mas os fenômenos não são estáticos no tempo. O pesquisador deve interpretar o que está acontecendo e incorporar as mudanças observadas à anterior conceituação; caso contrário, o conceito torna-se uma espécie de camisa de 
força, que contribui antes para ocultar do que revelar, ou passa a ter uma validade muito curta.

Alguns autores seguem limitando o conceito de gentrificação à construção original. A antropóloga de Barcelona Irene Sabaté Muriel (2019, p. 234), por exemplo, acredita que a utilização do conceito de maneira pouco delimitada acaba fazendo com que se trate como gentrificação algo que não guarda a característica de retorno das classes médias do subúrbio em direção das áreas centrais das cidades anglo-saxônicas. Parece-nos exageradamente limitadora tal perspectiva, pois desse modo seria muito difícil trabalhar com o processo de gentrificação em outros lugares, inclusive nas cidades do sul da Europa, que não se caracterizaram pelo movimento da classe média para bairros periurbanos. Também é possível observarmos a utilização de outras expressões como, por exemplo, especulação e expulsão de inquilinos; extração das rendas do trabalho mediante à imposição de aluguéis abusivos. Ou seja, não se trata de outra expressão para gentrificação, mas são basicamente frases explicativas...

O sociólogo Paulo Cesar Xavier Pereira (2016, p. 2) também pontua o esvaziamento do sentido da expressão gentrificação. Acredita ele que a sua associação, em âmbito global, a expressões como revitalização, remodelação, restauração ou renovação urbana acaba por retirar da categoria gentrificação a ideia de conflito social e de contradição. Reforça ainda que desconectado da noção de rent gap ${ }^{l}$, esse processo torna-se ainda mais esvaziado. Não nos resta dúvida de que Pereira (2016) apresenta elementos importantes em sua análise, por exemplo quando apresenta a fundamental relação entre gentrificação, rent gap e a teoria do valor. Contudo o autor expõe conclusões com as quais não concordamos. Afirma Pereira (2016, p. 3) que

a palavra gentrificação ganhou atributos de positividade ao descrever os melhoramentos urbanos como resultado de intervenção público-privada capaz de escolher os melhores usos e distinguir essas áreas na cidade, por isso essa noção perde força de contestação e seu caráter de denúncia se esvazia ao prevalecer como resultado os efeitos práticos e materiais da reurbanização.

Aqui temos um problema, pois não é novidade a apropriação (e distorção) pelos atores sociais - sejam os empreendedores imobiliários e os empresários do setor construtivo, sejam os governantes - de construções teóricas feitas pela academia para explicar os processos em curso. Recentemente, na cidade do Rio de Janeiro, presenciamos uma espécie de "rapto ideológico" da expressão "legado olímpico". Esse termo foi cunhado pela academia para criticar a proposta do projeto olímpico para a cidade do Rio de Janeiro, que não estaria trazendo benefícios para os moradores da cidade. A equipe da prefeitura, alguns deputados e alguns vereadores passaram a utilizar a expressão para justificar as obras por que passava a cidade. Nem por isso precisamos criar outra expressão para continuar fazendo a crítica; ao contrário, continuamos inquerindo qual seria o "legado olímpico" (termo que passou a ser de conhecimento do grande público) para mostrar como

\footnotetext{
${ }^{1}$ Em breve esclareceremos o significado dessa expressão.
} 
os governantes estavam ludibriando os cidadãos. Passamos a questionar o legado proposto pelo projeto olímpico, e mais do que isso, a inquerir à população sobre seu legado sonhado. Nas próximas páginas esperamos deixar ainda mais claro porque acreditamos que a expressão gentrificação não deve ser abandonada; e mais do que isso, por que sua definição precisa ser complexificada, além de aproveitarmos, também, o fato do termo já ser de conhecimento e uso pelo cidadão comum e pelos movimentos sociais.

Defendemos firmemente a ideia de que os processos estão em movimento e que cabe aos pesquisadores analisar aquilo que está de fato acontecendo. A construção teórica deve servir para nos ajudar a compreender o que está sendo investigado; por isso defendemos a ideia de que é preciso continuar retrabalhando os conceitos, emprestandolhes maior complexidade para que sigam ajudando-nos a compreender as mudanças por que estamos passando nas cidades. Essa perspectiva do fazer científico não é nova, temos vários exemplos de categorias analíticas que tiveram suas definições alteradas e bastante complexificadas, como por exemplo: território, espaço, movimento social etc. Ademais, como nos lembra Lencioni (2006, p. 42), "os conceitos são concebidos e devem revelar universalidade, por assim dizer, expressar abrangência sem ter que expressar todas as particularidades do que está sendo considerado". Até porque, de outra maneira, acabariam servindo apenas para explicar algo extremamente específico e único em suas características. Por isso, "a pertinência de um conceito não é medida porque ele contém todas as propriedades, aspectos, características ou movimento do que está sendo considerado, mas porque ele exprime sua essência” (LENCIONI, 2006, p. 42). Em se tratando da gentrificação, acreditamos que está em sua essência o caráter espoliativo, já que - como afirmamos anteriormente - após o investimento em infraestrutura, em novas construções ou a divulgação de um grande projeto de renovação urbana, há uma maior valorização de determinado lugar, assim os antigos moradores não resistem ao encarecimento do local, tendo que buscar outra área com custo de vida mais baixo.

Posto isso, debruçar-nos-emos sobre o processo de gentrificação e suas possíveis variações. Dependendo do país, da região e do lugar na cidade, o processo ganha determinadas características, mas sempre tendo como resultado - em menor ou maior grau - a expulsão dos antigos moradores e frequentadores. Esta certeza é que levou o sociólogo alemão Andrej Holm (2010, p. 320) a afirmar que
a gentrificação é qualquer processo de revalorização de uma parte da cidade, ligado a estratégias imobiliárias e econômicas que elevam o valor e/ou a estratégias políticas de revalorização, que requerem uma substituição de população para ter êxito. A expulsão é a essência da gentrificação, não um efeito colateral indesejado.

Desenvolveremos adiante essa ideia de não se tratar de um efeito colateral, posto que é estrategicamente planejada.

Há vários fatores que colaboram para o processo de gentrificação, entretanto cumpre importante papel a emergência do denominado rent gap em bairros históricos do centro da cidade (mas também para além dessas áreas) - conforme desenvolvido pelo 
geógrafo estadunidense Neil Smith $(1979,1987)$-, em que a disparidade entre o nível de renda da terra potencial, tendo em vista sua localização e a possibilidade de retorno econômico de um projeto futuro, e a real renda da terra capitalizada sob o seu uso atual são fundamentais para a implementação de programas de revitalização ou renovação urbana. A expectativa da possibilidade de conseguir um uso mais rentável acaba gerando já uma especulação. Esse fenômeno vem se repetindo nas cidades mundo afora.

Em certos bairros de Lisboa e de Barcelona (mas não apenas nessas duas cidades), por exemplo, observamos que a expulsão dos moradores não se dá através da substituição populacional. Na verdade, os moradores estão sendo substituídos por uma espécie de população flutuante de turistas; ou seja, há a expulsão, mas não por novos moradores fixos.

Em se tratando de Lisboa, esse perfil de gentrificação turística afetou fortemente determinados bairros, como Alfama, Mouraria, Castelo, Baixa, Chiado, Madragoa e o Bairro Alto. Estas localidades, com característica de bairros históricos e com habitação e comércio tradicionais, estão sendo fortemente transformadas; percebemos a expansão de funções de lazer, recreação e de toda forma de alojamentos turísticos. Aliás, houve uma expansão desregulada do alojamento local, uma implementação de programas de atração de investimento estrangeiro e da financeirização da habitação.

O geógrafo português Luís Mendes ${ }^{2}$ demonstrou preocupação com o que vem testemunhando em Lisboa e afirmou que

a gentrificação tornou-se madura e afigura-se com contornos mais agressivos, o que implica desalojamento dos pobres e uma perspectiva da habitação esvaziada da noção de direito, para ganhar o estatuto de mero ativo financeiro para atração de investimento estrangeiro.

Os preços dos imóveis em Lisboa e arredores seguem em ascensão - mesmo durante a pandemia que assolou a humanidade em 2020 -, fato que tem contribuído para a expulsão de moradores da capital portuguesa. Se observarmos a variação da média do preço do $\mathrm{m}^{2}$ em Lisboa de dezembro de 2018 a junho de 2020, percebemos que em um ano e meio passou de $€ 4.161$ para $€ 4.664^{3}$; uma variação de $10,78 \%$, mas em alguns bairros das áreas centrais a variação chegou a mais de $22 \%$.

Parece que a combinação dos fluxos de capital no mercado imobiliário com a mudança econômica e política para o turismo explica melhor a gentrificação que vem ocorrendo em Lisboa. Não à toa, Mendes (2017, p. 490) enaltece o fato de que o aumento vertiginoso do preço da habitação

\footnotetext{
2 https://jornaleconomico.sapo.pt/noticias/o-processo-de-gentrificacao-em-curso-nas-cidades-e-periferias-delisboa-e-porto- 264850

${ }^{3}$ https://www.idealista.pt/media/relatorios-preco-habitacao/venda/lisboa/lisboa/
} 


\begin{abstract}
para uso permanente ou temporário (arrendamento ou aluguel) tem empurrado para fora as pessoas pobres e os imigrantes, de modo que atrações turísticas, restaurantes, bares de entretenimento e lojas para visitantes e turistas dominam agora grande parte dos distritos centrais.
\end{abstract}

A cidade do Porto, em Portugal, também passa por semelhante processo, entretanto a velha área central já experimentava um processo de relativo esvaziamento de seu conjunto arquitetônico devido à degradação dos imóveis. A opção pela denominada "economia de serviços" demonstrou a cada vez maior dependência da atividade turística. Essa escolha tem provocado a saída de famílias inteiras, além de contribuir para a destruição da antiga economia de bairro através do fechamento de mercearias, barbearias, associações culturais, tabacarias, ateliês de jovens artistas, pequenas padarias e açougues.

Observamos uma intensa mudança no perfil dos moradores, do comércio e dos serviços. Torna-se comum ouvir diariamente pessoas falando outras línguas, e que passam dois ou três dias na cidade e logo vão-se embora. O barulho das malas de rodinhas tornouse algo normal no dia a dia daqueles habitantes que insistem em permanecer ali. Tudo isso é acompanhado pelo crescimento do número dos alojamentos locais alugados por curto prazo. A verdade é que o turismo tem tido forte impacto na cidade do Porto, levando à substituição de boa parte da população local. O arquiteto português Pedro Levi Bismarck ${ }^{4}$, do Centro de Estudos de Arquitectura e Urbanismo, afirma que se trata de um processo claro e que "basta ver os despejos que têm ocorrido um pouco por todo o lado, sobretudo nas 'ilhas', mas também a subida generalizada e incomportável dos arrendamentos que impossibilita um acesso qualificado à habitação". De 2001 a 2011, por exemplo, o Centro Histórico do Porto perdeu cerca de $30 \%$ da população residente ${ }^{5}$. O pesquisador acredita que a cidade, cada vez mais gentrificada e turistificada, "é produto de uma economia que recusa qualquer planificação ou intervenção do Estado", e acrescenta ainda "que se aceita a lógica do mercado como sendo única e natural, assim como a conversão da habitação num ativo financeiro a ser rentabilizado e não num direito de todos". Dá-se a produção do espaço em um momento em que a racionalidade neoliberal induz à produção da cidade através da exacerbação da dimensão econômica em detrimento das outras dimensões da vida. Essa racionalidade colabora com a expropriação dos bens comuns e com o desmantelamento das instituições públicas.

Em Barcelona, o setor turístico gera mais de 20 milhões de euros por dia, isto equivale a cerca de $12 \%$ do seu PIB, ou mais de $20 \%$ se contarmos com o impacto indireto $^{6}$. Os bairros do distrito da Ciutat Vella em Barcelona, que é composto pelos bairros El Raval, El Barri Gotic, La Barceloneta e Sant Pere, Santa Caterina i la Ribera, também passou por forte processo de gentrificação turística. Aproximadamente $52 \%$ dos

\footnotetext{
4 https://jornaleconomico.sapo.pt/noticias/o-processo-de-gentrificacao-em-curso-nas-cidades-e-periferias-delisboa-e-porto-264850

${ }^{5}$ ALVES, Sónia. Requalificação e gentrificação no Centro Histórico do Porto. Scripta Nova. Revista Electrónica de Geografía y Ciencias Sociales. Universidad de Barcelona, Vol. XXI, N. 557, 28 de febrero de 2017.

${ }^{6}$ https://www.esquerda.net/dossier/barcelona-o-bairro-gotico-paradigma-da-turistificacao-da-cidade/44795
} 
imóveis são ocupados por turistas ou por moradores de curta duração. Em termos numéricos, no final de 2015 existiam na cidade aproximadamente 15.000 apartamentos inscritos no Airbnb (ou seja, 2,5\% dos domicílios). O problema torna-se mais evidente se mirarmos as áreas centrais da cidade, já que na Ciutat Vella esse número sobe para cerca de $10 \%$. No Barri Gotic, por exemplo e assustadoramente, a proporção é de aproximadamente $17 \%$ de apartamentos registrados no Airbnb e mais da metade dos edifícios desse bairro - o equivalente a 52\% - contém andares turísticos.

Os antigos inquilinos viram-se em meio à não renovação dos contratos de aluguel e à degradação proposital das habitações, estratégias que têm sido usadas para forçar os moradores a sair. Os pesquisadores espanhóis Agustín Cócola Gant e Antonio López Gay calcularam que $17,6 \%$ da população abandonou o bairro entre 2006 e $2016^{7}$. Os problemas no Barri Gotic vão além da questão da moradia, pois o comércio e vida cotidiana são bastante afetados. O comércio de bairro, como a farmácia, a padaria e o açougue, é substituído por negócios voltados ao turismo, o que também dificulta a permanência dos antigos moradores.

A cidade do Rio de Janeiro experimenta processo semelhante principalmente e de maneira mais intensa, a partir dos anos 1990; no entanto, por diversas razões, as propostas de revitalização acabaram não se concretizando plenamente. Contudo, um alinhamento dos governos federal, estadual e municipal, a partir da primeira década do século XXI, pôs em prática a transformação da zona portuária e arredores. Para tanto é utilizada uma estratégia agressiva de marketing em que o que está sendo vendido é a cidade.

As administrações municipais propuseram ao longo desses anos vários projetos, alguns não se concretizaram, outros concretizaram-se em parte. Houve uma proposta, que chegou a ter um projeto apresentado por um arquiteto francês, de construção de uma filial do Museu Guggenheim, que se localizaria na baía de Guanabara (seria um museu flutuante). Houve a demolição do viaduto da Perimetral (eixo de circulação importante na área central da cidade) para devolver a vista para o mar, tão marcante na história inicial da cidade. Um dos objetivos desse projeto era a construção de habitações para a classe média e média alta da sociedade, além de shoppings e restaurantes na parte mais nobre desse litoral. Havia a proposta de construção de casas de espetáculo, museus de design, edifícios de escritórios e lojas de grifes internacionais (FERREIRA, 2013a, 2013b).

Todavia, vale acrescentar que a cidade do Rio de Janeiro, com sua frente marítima belíssima e com forte apelo turístico - lembremos de Copacabana, Ipanema, Leblon e, mais recentemente, a Barra da Tijuca -, pode ter deixado em dúvidas o empresariado no que se refere à possibilidade de investir na velha zona portuária, que se tornou obsoleta há algum tempo. Ou talvez tenha mesmo sido uma estratégia de rent gap; em outras palavras, uma estratégia para gerar uma considerável redução do preço do $\mathrm{m}^{2}$

\footnotetext{
${ }^{7}$ https://www.esquerda.net/dossier/barcelona-o-bairro-gotico-paradigma-da-turistificacao-da-cidade/44795
} 
da área. Assim, houve pouca pressão dos promotores imobiliários junto aos governos anteriores para a implementação de obras naquela área.

Fato é que ao final da primeira década do século XXI, o alinhamento das três esferas de governo em associação com os interesses das grandes construtoras, do setor financeiro e dos promotores imobiliários voltaram os olhos para a zona portuária da cidade. Não foi coincidência o fato de termos vários eventos internacionais sediados na cidade nesse período: Rock in Rio de 2011; Terceira Cúpula da Terra (a Rio+20) (2012) - nesse ano a cidade tornou-se também patrimônio da humanidade da UNESCO na categoria "Paisagem cultural" -; Jornada Mundial da Juventude (2013); Copa do Mundo de Futebol (2014); e Olimpíadas de 2016.

A prefeitura colocou em ação um projeto de "revitalização da zona portuária" chamado pela prefeitura de Projeto de Revitalização Porto Maravilha (Figura 1). A revitalização da zona portuária teve como objetivo a atração de empresas, a melhoria da infraestrutura turística do porto e a edificação de inúmeros prédios corporativos (Figura 2). Durante o lançamento do projeto, falou-se que a revitalização beneficiaria algo em torno de 400 mil turistas, que anualmente chegam ao porto do Rio, e também os cerca de 25 mil moradores, que poderiam aproveitar as transformações para lazer e entretenimento (fato que obviamente não ocorreu - até porque estamos apontando para a ocorrência da gentrificação).

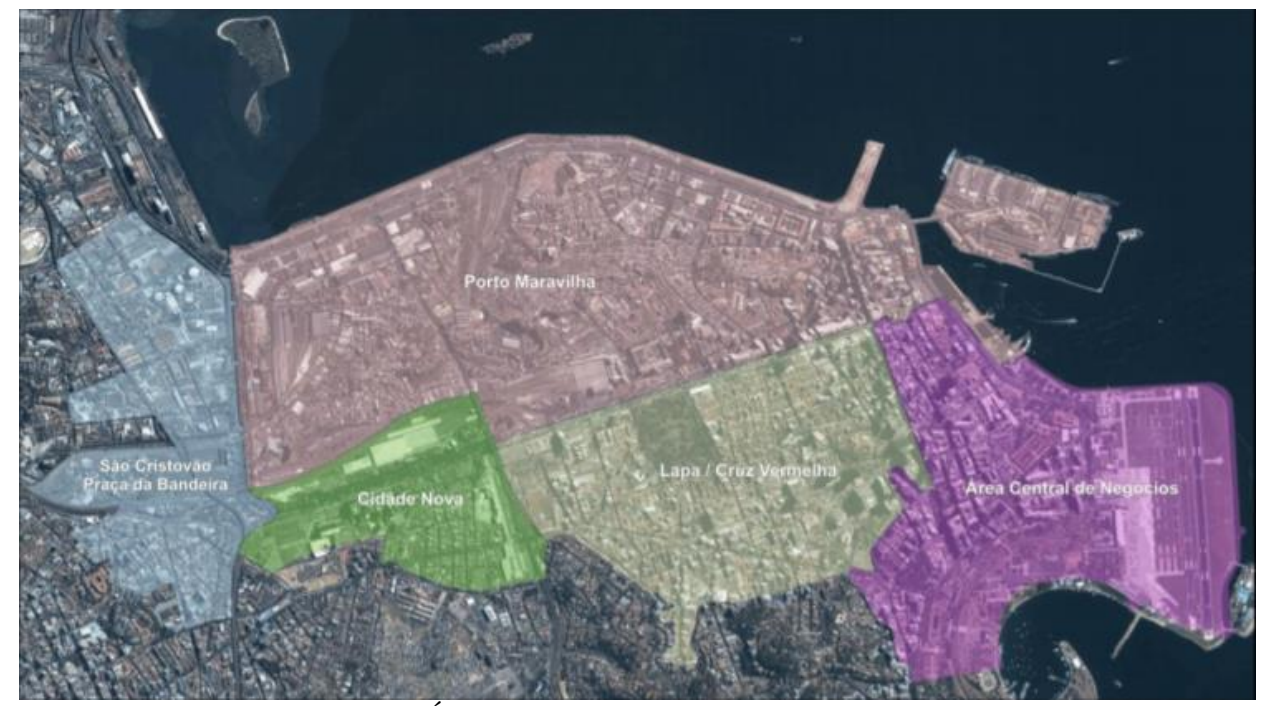

Figura 1: Área demarcada do Projeto Porto Maravilha.

Fonte: Operação Urbana Consorciada da Região do Porto do Rio (2012).

Outra localidade, bem próxima do Píer Mauá, que também recebeu investimentos foi o Morro da Conceição. Situado no centro antigo da cidade, com o casario em arquitetura colonial portuguesa, é visto como grande potencial para o turismo e sofreu intervenções em sua rede elétrica (que passou a ser subterrânea), suas ruas (que foram 
reformadas) e o casario histórico, que foi em parte restaurado. Inclusive, constava do projeto a construção de um teleférico, que ligaria o Museu de Arte do Rio (MAR) ao Morro da Conceição; as gôndolas partiriam do terraço e iriam direto ao morro, entretanto esta parte do projeto (ainda) não foi realizada. A história do Rio de Janeiro está representada em exposição permanente e o teleférico faria com que a visitação saísse das salas da Pinacoteca e chegasse aos pontos históricos - então transformados em pontos turísticos prontos para serem "vendidos" - como a Pedra do Sal, a Fortaleza da Conceição, a Igreja de São Francisco da Prainha e o Observatório do Valongo. Contudo, perguntamonos se aqueles que lá moram, em um bairro tranquilo no coração da cidade, gostariam de ter seu cotidiano invadido por inúmeros turistas. Ou se ocorrerá ali o que já ocorreu em outros centros históricos, que depois de valorizados têm impossibilitado a permanência de seus antigos moradores no local (FERREIRA, 2013a, 2013b).

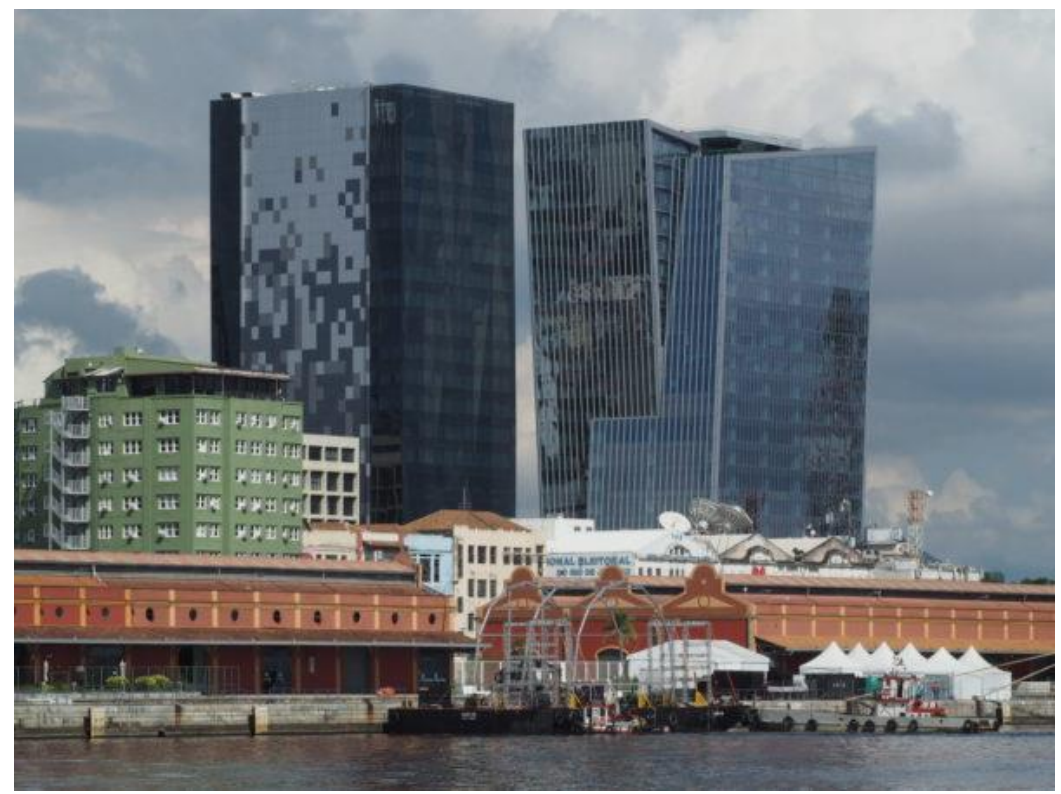

Figura 2: Prédios corporativos na zona portuária da cidade do Rio de Janeiro. Fonte: Diário do Porto (2018).

A parceria público-privada foi utilizada para a implementação do Museu do Amanhã (Figura 3), destinando-se a exposições interativas, com enfoque no tema da relação do ser humano com o planeta. Uma estratégia econômica, que se aproveitou de um momento em que se fala cada vez mais em aquecimento global, efeito estufa, sustentabilidades, etc. Seguindo o caminho trilhado por outros prefeitos, ou seja, a utilização da denominada arquitetura de assinatura, o Museu do Amanhã foi projetado pelo arquiteto espanhol Santiago Calatrava. O prefeito carioca foi ao encontro da máxima que vê esses grandes projetos arquitetônicos de grande monumentalidade como alavancadores de investimentos para as cidades. 


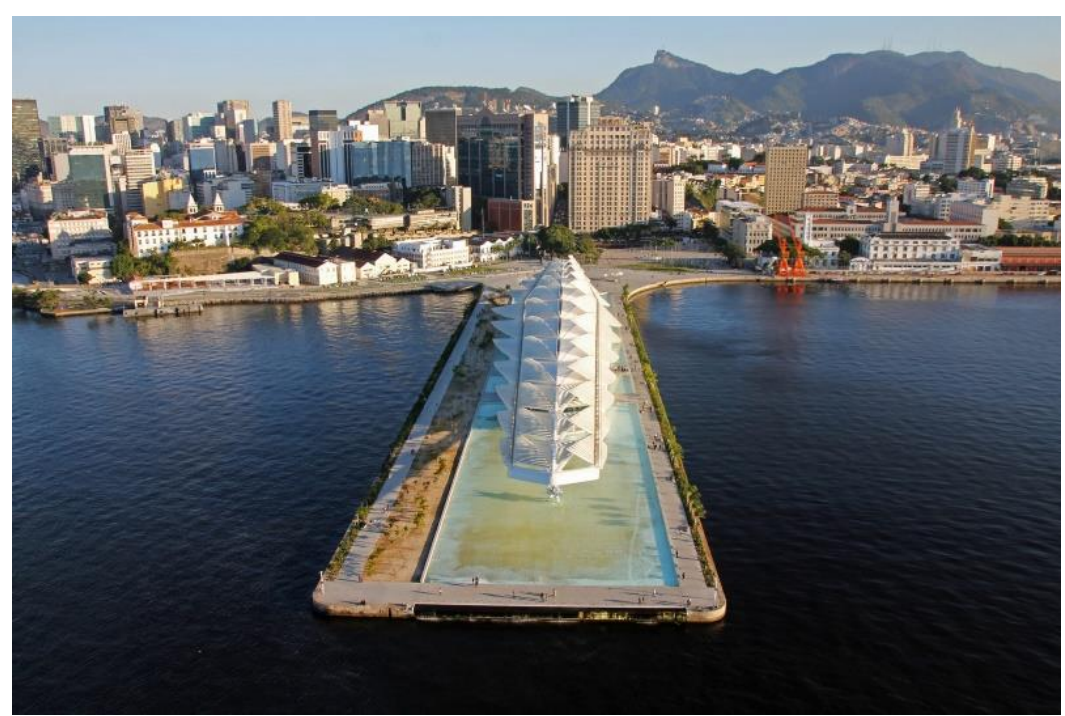

Figura 3: Museu do Amanhã - Projeto de Santiago Calatrava para a zona portuária carioca. Fonte: Pública (2016).

Não temos o objetivo de aprofundar-nos com mais pormenores sobre as características da gentrificação ocorrida nessas cidades a que nos referimos até agora. Utilizamo-las como exemplo, apenas para começar a deixar claro que - ao contrário do que muitos defendem - o processo de gentrificação não é algo natural, mas planejado.

\section{Gentrificação: efeito colateral indesejado?}

Ao contrário do que possa parecer, nem todos os discursos veem a gentrificação como um problema. Ao debruçar-nos sobre o debate público acerca da gentrificação, é possível observar inúmeros discursos que, a título de exemplo, podemos apontar como o negador, o minimizador, o positivador e o criminalizador8.

O primeiro simplesmente nega a existência da gentrificação atualmente, afirmando que esse processo aconteceu em determinada localidade de Londres na década de 1960. O segundo exemplo - como seu próprio nome deixa transparecer - minimiza uma característica importante da gentrificação, que é a expulsão dos antigos moradores. Aqui se enaltece a revalorização do bairro, um renascimento, logo vê o fenômeno como algo bom, já que foca nas reformas dos prédios e praças deteriorados. $O$ terceiro não nega a ocorrência da gentrificação, mas a vê como algo extremamente positivo, visto que o investimento nos bairros "problemáticos" melhora as condições do local, e se para isso os antigos "moradores problemáticos" tiverem que sair, isso ocorre para um bem maior (?!). Finalmente, o quarto discurso chega a ser ainda mais absurdo e muitas vezes vem

8 Para um maior aprofundamento desse debate, sugerimos ver VOLLMER, Lisa. Strategien gegen Gentrifizierung. Berlin: Schmetterling Verlag GmbH, 2018. 
associado aos outros três: "a gentrificação não existe e é apenas um termo inventado pela extrema esquerda, pelos comunistas". Mas porque será que esse processo gera tanto debate? Talvez possamos entender melhor tudo isso se percebermos que a gentrificação é um processo que se materializa no lugar, mas há inúmeros atores e agentes por trás desse processo e há, inclusive, um projeto de cidade. Por isso, partimos do que se apresenta a nós enquanto formas construídas, mas é preciso investigar o que está por trás dessas formas e que projetos de mundo lhes dão sustentação. Não é à toa que para Smith (1979), a gentrificação é um movimento de retorno à cidade, todavia não um retorno das pessoas, mas do capital. Aliás, o próprio movimento de suburbanização nas cidades estadunidenses foi fruto de um projeto dos atores sociais que viram esse processo como um grande negócio; e claro, a mídia cumpriu um importante papel na construção desse imaginário social. O mesmo se dá hoje com o discurso de retorno ao centro. É como dizem os investidores e especuladores: business is business!

Vivemos uma intensa mercadificação do espaço e esse processo ocorre a partir de relações de poder bastante desiguais, como, por exemplo, entre a indústria da construção associada aos promotores imobiliários e as classes mais pobres de inquilinos. É importante ter isso em conta, pois de outra maneira corremos o risco de criarmos "culpados" de uma forma simplificadora. Lembremos que é preciso ir além das formas e discursos que se apresentam na "superfície"; temos de desvelar aquilo e aqueles que se encontram por trás do que se apresenta. Em outras palavras, não é o caso de culparmos a abertura da nova cafeteria ou da nova butique, que são vistas como responsáveis pela mudança nos estilos e hábitos de consumo dos lugares. Além disso, como nos lembra a pesquisadora alemã de História Urbana Lisa Vollmer (2019, p. 32), se entendermos a gentrificação apenas como embelezamento dos bairros, então a solução contra a gentrificação seria a luta contra essas melhorias, o que seria um absurdo. Analisando a partir dessa lógica simplificadora acabamos cegados; ou, parafraseando Marx (2007, 2005), passamos a ver um mundo encantado, invertido e de cabeça para baixo. Acabamos percebendo o que nos cerca de forma fetichizada; não vemos o jogo de relações sociais, mas apenas coisas: a cafeteria, a butique, a praça, o novo calçamento etc...

Se desejamos realmente lutar contra a gentrificação, é necessário entendê-la como estratégia imobiliária e, inclusive, de governo. Isso se dá, pois na sociedade capitalista a moradia não é pensada com o objetivo de atender as necessidades habitacionais de quem precisa, já que a moradia é vista como uma mercadoria, e como tal deve gerar retorno econômico. Assim, quando uma empresa faz um investimento na compra de um terreno ou na construção de um empreendimento imobiliário, o faz apostando que com a futura venda ou com o futuro aluguel conseguirá um retorno econômico vantajoso. Como, em geral, se trata de um alto investimento, cada vez mais observamos a associação das empresas construtoras e dos promotores imobiliários com empresas do mercado financeiro. Aliás, tem sido usual que grandes corporações se envolvam no mercado imobiliário como forma de realização do capital. Além disso, as grandes corporações têm cada vez mais diversificado suas atividades e se tornado mais poderosas e influentes sobre as políticas de governo, visto que muitas delas têm mais volume de capital do que o PIB de inúmeros países. A Vanguard Group (o maior fundo de investimentos dos EUA) controla algumas das empresas mais poderosas do mundo, como 
Bank of America, Citigroup, JP Morgan Chase \& Co, Santander, Deutsche Bank, HSBC, Google, Microsoft, Apple, Facebook, Amazon, Johnson \& Johnson, GSK - Glacso Smith Kline, Siemens, Bayer, Unilever, Basf, Du Pont, Monsanto, Exxon Mobil, Shell, General Electric, Boeing, General Motors, Volkswagen, Rolls Royce, Coca Cola, Pepsico, Nestle etc.

Retornando ao debate anterior, sobre investimentos na compra de um terreno ou na construção de um empreendimento imobiliário, outros investimentos importantes dizem respeito ao entorno desses imóveis, e nesse caso os governos locais cumprem um importante papel; seja na reforma ou construção de parques e praças, seja na melhoria do sistema de transportes. Em outras palavras, a implementação de melhorias na infraestrutura é fundamental para o "sucesso" dos projetos de revitalização, de renovação urbana, ou seja lá que expressão os governantes usem.

Não é novidade o fato de que os investimentos se distribuam espacialmente de forma desigual na cidade. Mas é preciso que nosso olhar investigativo permita-nos enxergar aquilo que não está explícito, que se mantém oculto. É preciso perceber que a degradação de determinados bairros, o abandono de prédios, de antigos armazéns ou galpões e até o aumento da criminalidade são também parte estratégica do sistema capitalista de produção do espaço. É preciso ter em conta que possa ter estado em curso uma estratégia para gerar uma considerável redução do preço do $\mathrm{m} 2$ dessas áreas. Referimo-nos ao conceito de rent gap, já mencionado anteriormente. Ao provocar a desvalorização de determinado bairro ou área da cidade, simultaneamente se produz a possibilidade de - com um investimento menor do empresariado - conseguir um retorno econômico bem maior através da implementação de projetos de revitalização. Isso porque os custos para aquisição de imóveis pelos empresários no local em questão tornam-se muito mais baixos.

Para que o movimento de revalorização econômica se ponha em curso, são utilizadas estratégias de revalorização simbólica, estética e cultural. Nesse sentido, a criação de espaços de consumo cumpre um importante papel para a revalorização desses lugares. Tudo isso é muito bem planejado, pois os investidores precisam ter certeza de que a mudança de imagem do bairro atrairá a classe média para lá viver ou para frequentar os novos bares, cafés, restaurantes e lojas.

Para que a gentrificação aconteça, ocorre a mobilização de vários atores e agentes, e alguns acabam envolvidos na realização do processo sem a menor intenção de que ele ocorra. Poderíamos afirmar que a "forma clássica" do desenvolvimento da gentrificação passaria por três fases, embora a implementação da gentrificação não necessariamente obedeça esse caminho.

Na primeira fase dessa "forma clássica", jovens que não têm como pagar aluguéis mais elevados, procuram localidades com imóveis em pior estado de conservação ou com perfil de rendimento mais baixo. Muitas vezes esses locais são menos visados e possibilitam o surgimento de empreendimentos "ditos criativos", como a criação de ateliês, a organização de festas informais, a abertura de um bar com características diferenciadas etc. 
Essas mudanças por que passa o bairro ou o local, leva-nos a segunda fase: a alteração da percepção do bairro. E esse tipo de mudança é apresentado por Vollmer $(2019$, p. 79) como a transformação da percepção do bairro como pobre e perigoso para a de um local jovem e interessante. Os jornais e revistas passam a fazer reportagens sobre os eventos e atrativos do bairro e isso cada vez atrai mais atenção dos novos frequentadores. E aqui parece importante acrescentar uma observação advinda de Andrej Holm (2010), que afirma que "os bairros que vivem dinâmicas de revalorização deixam de ser recipientes da atividade cultural e passam a ser um objeto cultural em si mesmos".

Como já vimos deixando claro anteriormente, o Estado cumpre também um papel importante em todo esse processo. O fato é que há uma associação entre o setor financeiro, a indústria da construção, os promotores imobiliários e a própria classe política (seja representando o interesse desses atores, seja investindo pessoalmente naqueles bairros com o objetivo de receber elevado retorno a seus investimentos).

As obras de infraestrutura e de embelezamento promovidas pelos representantes do governo também são fundamentais; aliás, são elas que cumprem o papel de incentivar os empresários e a transmitir a eles a certeza de que não haverá riscos para seus investimentos. O Projeto Porto Maravilha no Rio de Janeiro é um bom exemplo disso, e obviamente não é o único.

A terceira fase corresponde à passagem do que se denomina capital cultural (ligado ao espaço) para capital econômico. Nesta fase é fácil imaginar o que acontece: os promotores imobiliários utilizam a mídia para "vender" a nova imagem do local e os proprietários dos imóveis aumentam os preços dos aluguéis. Evidentemente toda essa transformação acaba por levar à expulsão da população antiga do bairro, que não consegue mais arcar com o custo de permanência ali. Eis aqui uma realidade cruel: a população que ali vivia acaba por não se beneficiar da melhoria das condições de vida do lugar, justamente porque não poderão continuar morando lá.

\section{A gentrificação para além da "forma clássica"}

Como procuramos deixar claro anteriormente, a definição de gentrificação ganhou muito mais complexidade, então o seu desenvolvimento "clássico" também ganhou novas configurações. O processo de gentrificação vai depender de múltiplos fatores, que estão ligados aos distintos contextos locais; em outras palavras, depende do alinhamento político entre as esferas de governo, do nível de implementação da racionalidade neoliberal na gestão pública e, por sua vez, do grau de organização e mobilização da população contra as injustiças sociais.

Retomando o debate acerca de como a gentrificação ganha características diferenciadas dependendo da estratégia traçada e da cidade envolvida, podemos afirmar que o processo pode envolver antigas áreas industriais e portuárias ou áreas residenciais. Além disso, múltiplos atores podem estar envolvidos; ou seja, referimo-nos aos investimentos governamentais, às empresas ligadas ao setor da construção, ao mercado financeiro e ao mercado imobiliário propriamente dito. 
Mesmo sabendo que as cidades são diferentes, vimos escrevendo há tempos sobre aquilo que denominamos banalização do espaço, situação em que os projetos de cidades se repetem mundo afora. Aquilo que teria dado certo em determinada cidade é copiado e reproduzido em outros locais, compondo uma espécie de urbanização banalizada. Esses projetos trazem em seu cerne propostas de renovação urbana que exacerbam a gentrificação, que se espalha por várias cidades, gerando insatisfação aos antigos moradores (Figuras 4, 5, 6, 7).

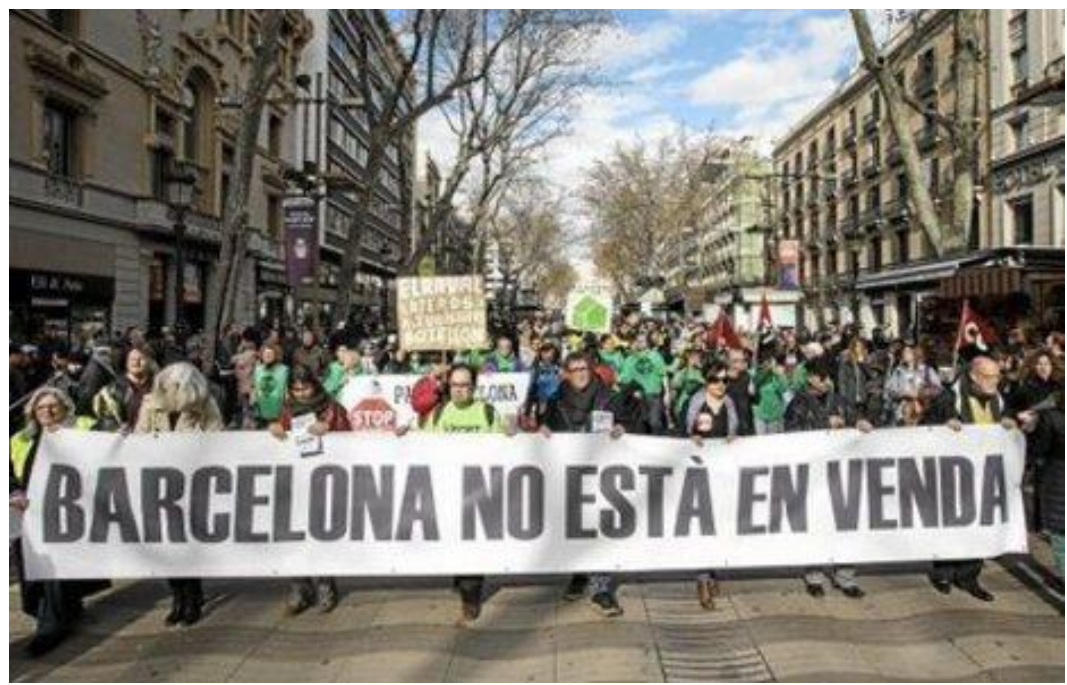

Figura 4: Barcelona - Passeata nas Ramblas.

Fonte: Observatorio del Turismo Irresponsable (2018).

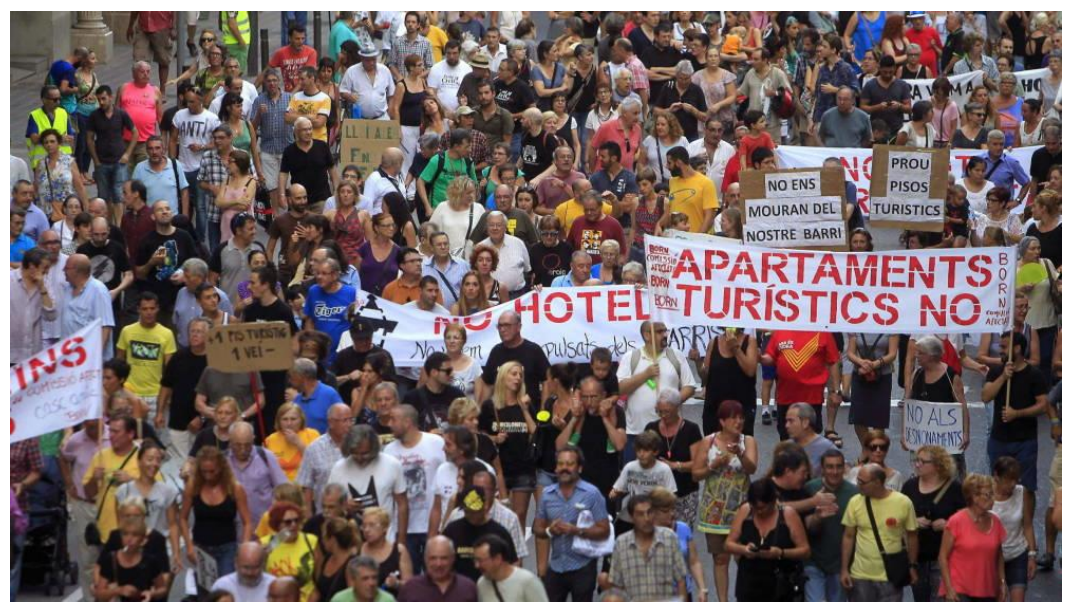

Figura 5: Barcelona - Movimento contra o Airbnb.

Fonte: Público (2017). 


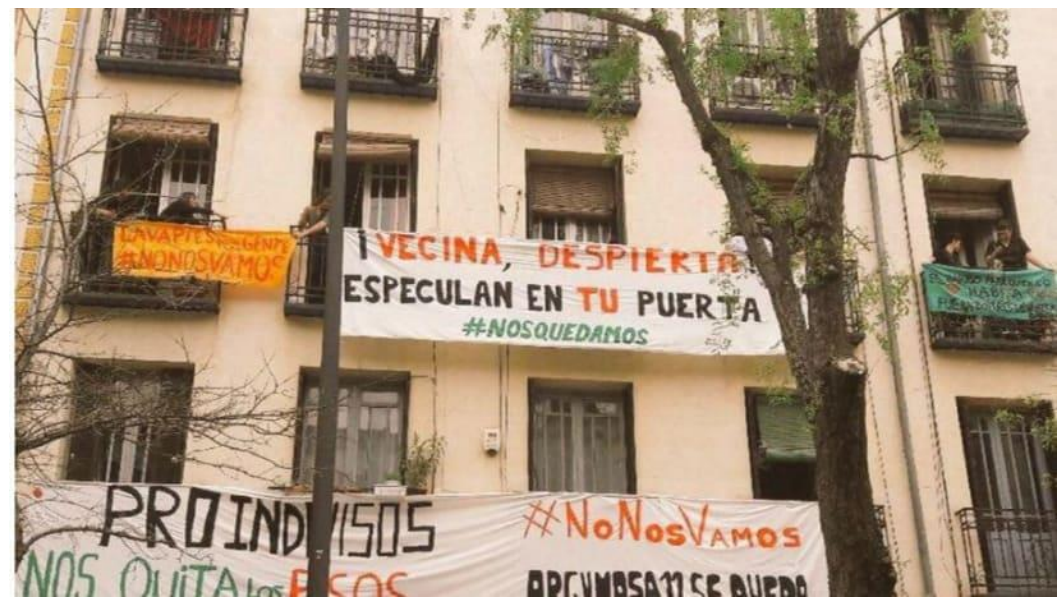

Figura 6: Madrid - Manifestação no bairro de Lavapiés. Fonte: Domestika (2018).

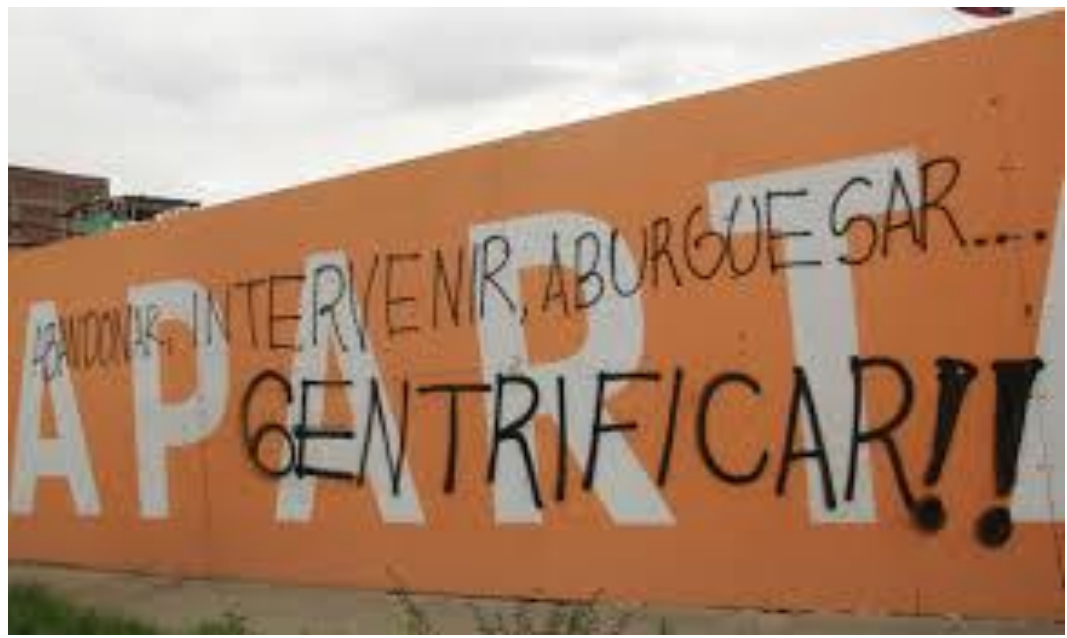

Figura 7: Pichação na Cidade do México.

Fonte: Geoativismo (2017).

Atualmente, a expressão gentrificação circula não apenas na academia, mas também nas reuniões dos movimentos sociais, na mídia e, por consequência, em órgãos de governo (que, em geral, procuram sempre negar o sentido negativo do processo). Não é mais possível pensar a gentrificação apenas restrita ao velho centro urbano das grandes metrópoles, pois ela se estende para outros bairros da cidade. Além disso, em cidades menores também é possível observar esse fenômeno. Trata-se de um processo que, como afirmamos anteriormente, se estende por cidades mundo afora. A gentrificação tem se expandido por cidades de todos os continentes, e isso levou o urbanista Rowland Atkinson 
e o geógrafo Gary Bridge (2005) a afirmarem tratar-se do novo colonialismo urbano (Figura 8).

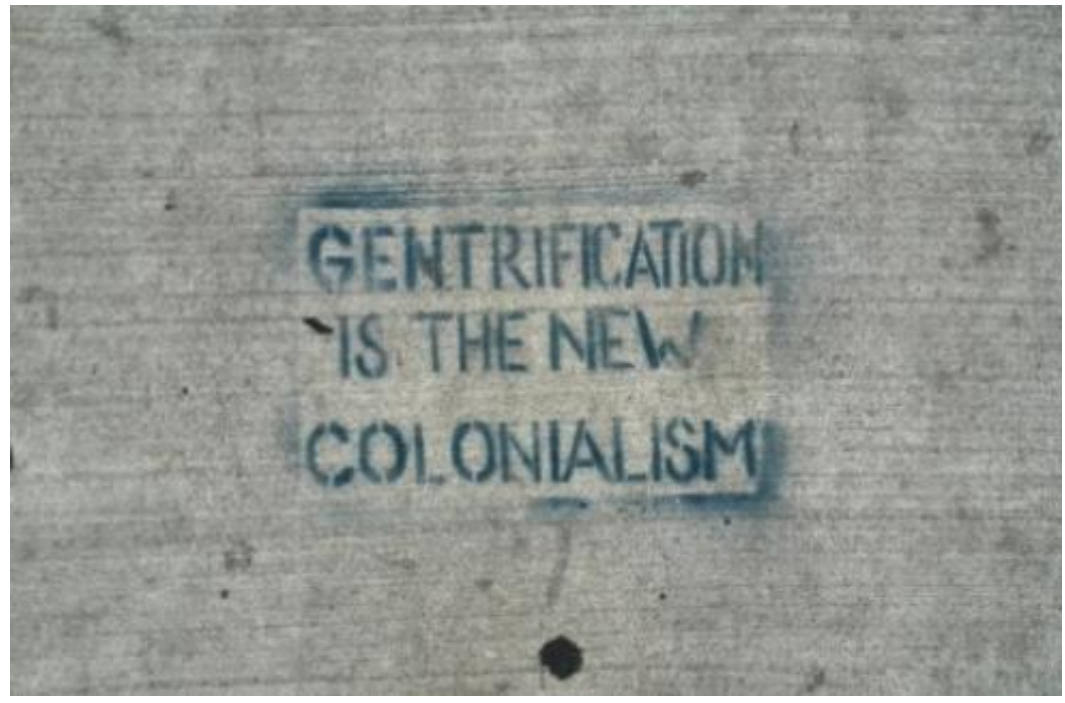

Figura 8: Lisboa - Gentrificação é o novo colonialismo. Fonte: Esquerda (2016).

Ao que parece, a racionalidade capitalista, buscando escapar das consequências de suas próprias crises de sobreacumulação, percebeu que os investimentos imobiliários servem muito bem à reprodução do capital; em outras palavras, o mercado imobiliário tornou-se um porto seguro e acabou por exacerbar ainda mais fortemente a gentrificação.

Entretanto muitos governantes, e mesmo integrantes da academia, fazem certa distinção quando se trata de uma construção nova. Defendem eles que ao se construir novas moradias não está havendo expulsão de quem quer que seja; e, nesse caso, não haveria gentrificação. Parece-nos uma posição estreita ou, em certos casos, até mesmo mal-intencionada, pois simplifica o processo e oculta o seu desdobramento. Dependendo do perfil da construção que está sendo edificada, podemos identificar um futuro aumento do preço médio do metro quadrado do bairro e, consequentemente, o aumento dos aluguéis. Além disso, os novos residentes - com rendimentos mais elevados - demandarão novos serviços e terão perfil de consumo diferente dos antigos moradores. Ou seja, surgirão novas lojas comerciais e de serviços, que tomarão o lugar do antigo comércio local, para atender a nova demanda. Esses novos negócios servem de incentivo aos investidores que projetam uma maior valorização daquela área no futuro próximo.

Soma-se também o fato de que o aumento dos preços fomentados pelas novas construções, acaba por gerar o aumento dos aluguéis dos antigos imóveis - muitas vezes reformados e transformados em apartamentos para aluguel de curta duração. Tudo isso acaba por, indiretamente, contribuir para a expulsão dos antigos moradores. Em outras 
palavras, está claro para nós que o investimento em novas construções - se não estiver acompanhado de uma política de criação de condições de permanência da população original - pode sim promover a gentrificação.

Temos, então, a construção de um ciclo vicioso em que o surgimento de construções novas promove a abertura de restaurantes mais caros, cafeterias e pequenas butiques, que por sua vez sinalizam aos investidores que vale a pena investir naquele local. Esse movimento dificulta cada vez mais a permanência dos antigos moradores.

O crescimento do número de apartamentos para aluguel de curta duração, que tem no Airbnb sua expressão máxima, colabora para a modificação do espaço público e da estrutura comercial dos bairros. Em outras palavras, as alterações são realizadas não para suprir as necessidades dos moradores originais, mas sim para atender aos hábitos de consumo dos turistas. Evidentemente, como vimos afirmando, isso tem gerado a insatisfação dos antigos residentes em várias cidades, gerando toda forma de protestos (Figuras 9, 10, 11 e 12).

Não é possível dissociar a gentrificação do atual processo de turistificação. Como procuramos deixar claro anteriormente, trata-se de uma característica diferente que assume a gentrificação. A substituição dos antigos moradores não se dá pela chegada de novos residentes com um perfil de rendimentos mais elevado, mas por visitantes temporários, que demandam serviços e comércios diferentes da anterior necessidade dos moradores. Além disso, inúmeros imóveis passam a ser destinados ao uso turístico, o que reduz a oferta de apartamentos para moradia fixa e acaba encarecendo os aluguéis.

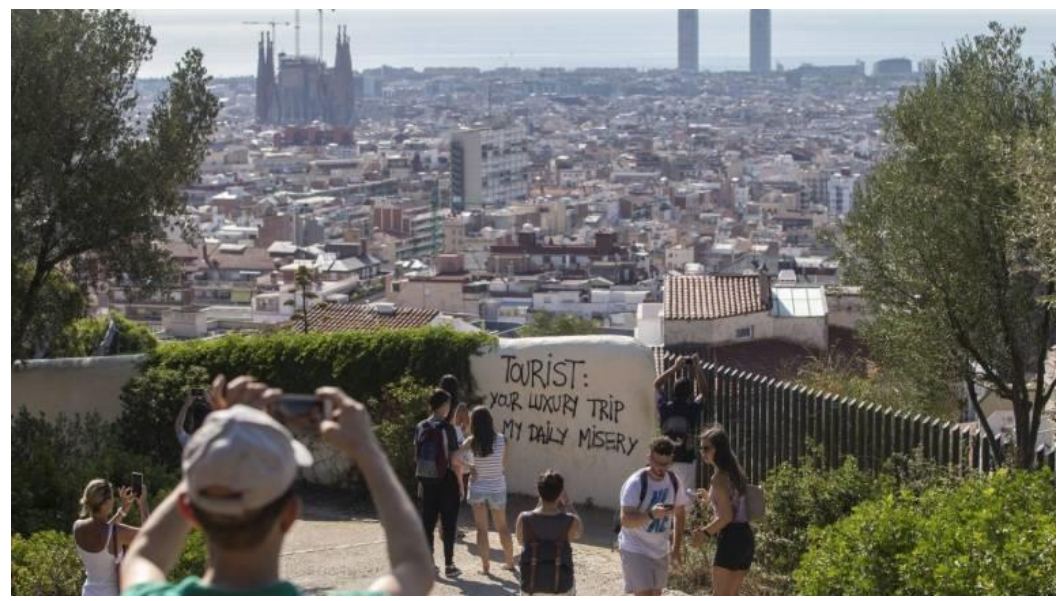

Figura 9: Barcelona: "Turista: sua viagem de luxo, minha miséria diária. Fonte: Valencia Plaza (2017). 


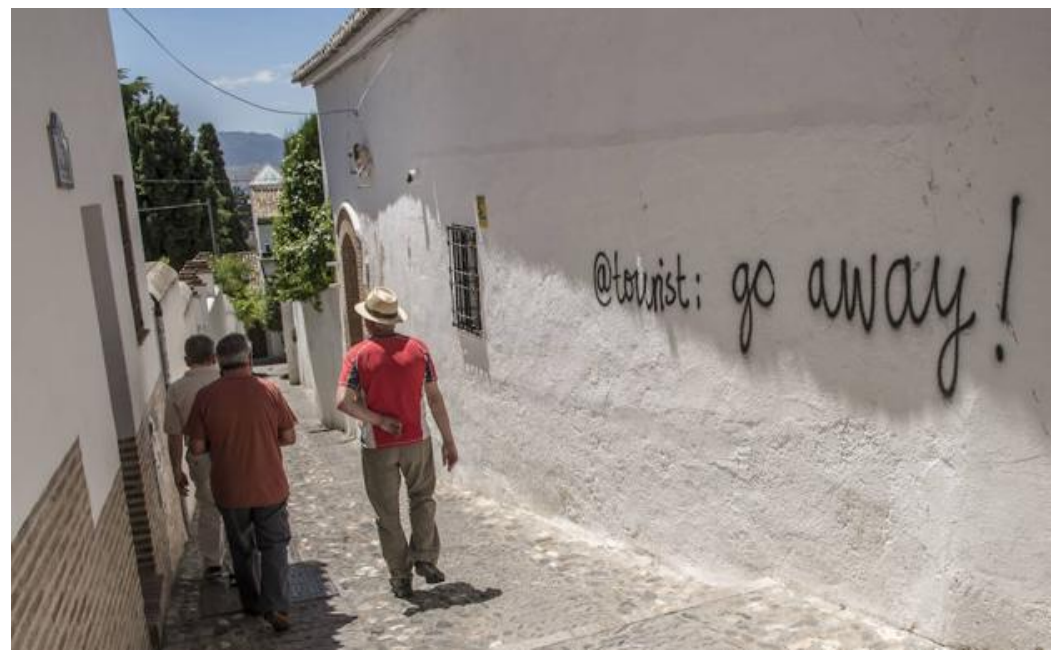

Figura 10: Granada: “@turista: vá embora!” Fonte: Ideal (2019).

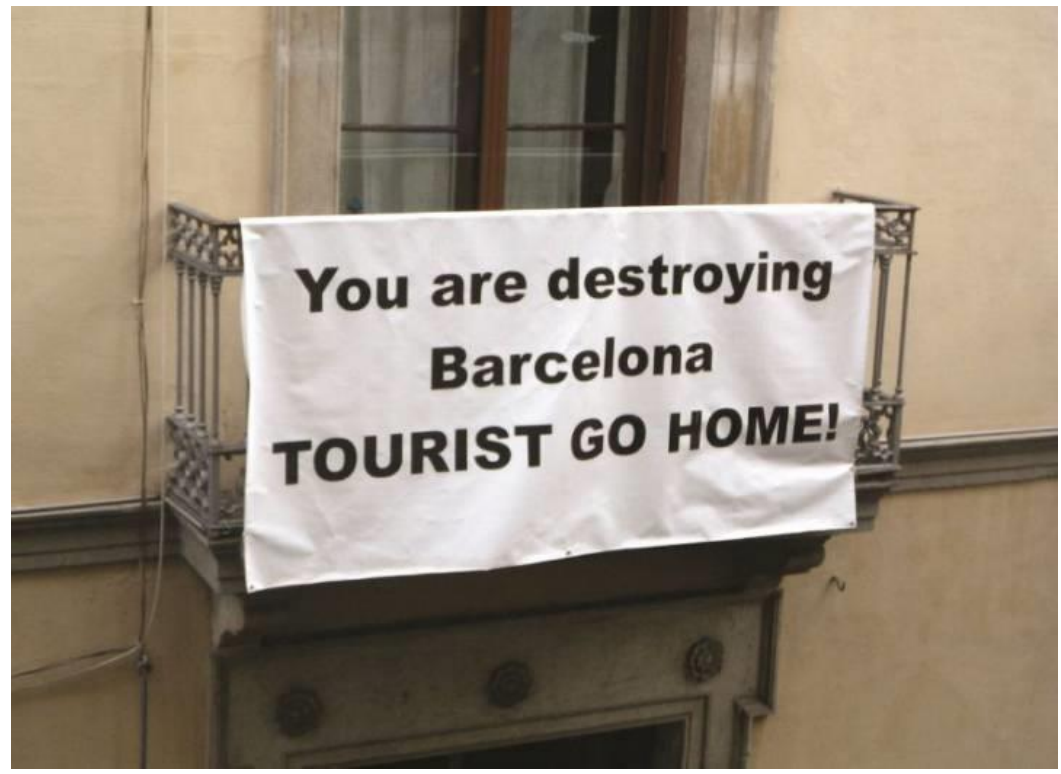

Figura 11: Barcelona: "Você está destruindo Barcelona. Turista volte para casa!" Fonte: Turismologia (2018). 


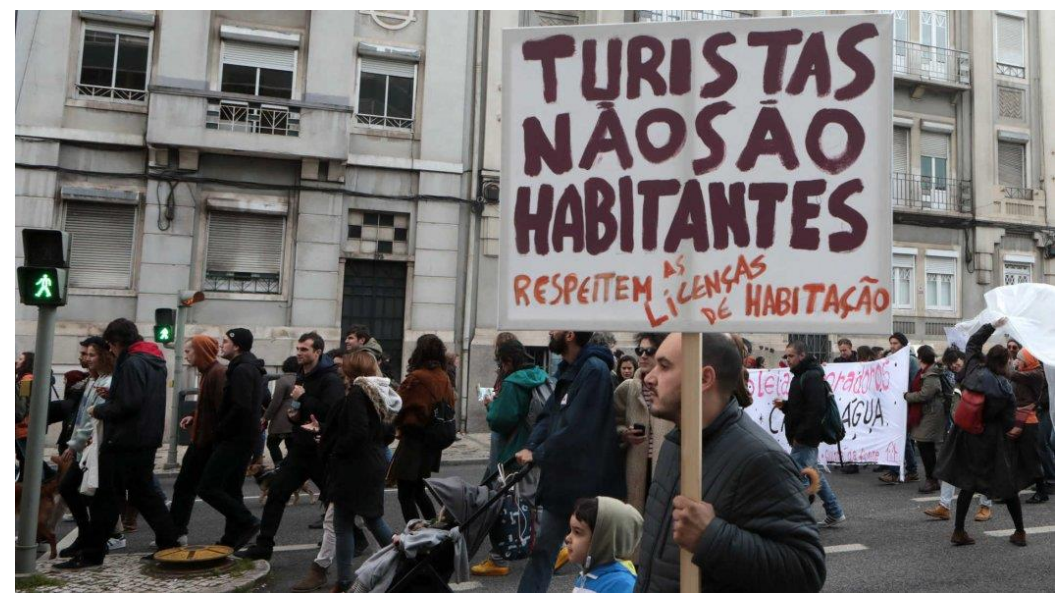

Figura 12: Manifestação em Lisboa.

Fonte: Dinheiro Vivo (2018).

Há outro ponto importante a indicar quando as políticas públicas priorizam a atração de turistas como estratégia de captação de recursos, já que o turista não está interessado no cuidado com o bairro, não reivindica melhorias de equipamentos públicos e, em geral, não está preocupado com a preservação do ambiente.

O caminho da turistificação é ele mesmo paradoxal; esclareço: ao tornar-se objeto do turismo de massa, a cidade tornou-se ela mesma uma mercadoria. Já deixamos claro anteriormente, em outras publicações, o conceito de mercadificação do espaço, é a partir desse sentido que afirmamos que as cidades são mercadificadas. Seguindo essa racionalidade, os empreendedores procuram "vender" as cidades, e para isso acabam copiando aquilo que "deu certo" em outros lugares. Com isso, vivenciamos uma homogeneização das paisagens turísticas das cidades, o que se mostra um paradoxo, visto que isso acaba por destruir as especificidades dos lugares; ou seja, aquilo que era o motivo da atração dos turistas - o diferente - acaba sendo transformado e homogeneizado. De alguma forma, trata-se daquilo que denominei banalização do espaço 9 , ou em outras palavras, na produção de uma espécie de urbanização banalizada.

Acreditam os arquitetos espanhóis Josep María Montaner e Zaida Muxí (2011, p. 148), que a desculpa do incentivo ao turismo e às obras para os grandes eventos servem para mascarar a especulação. Afirmam eles que "uma cidade posta à disposição do turismo de massa, serve para isso: para ser consumida". Acrescentam ainda que serve

para que os visitantes façam dela o que quiserem, até mesmo esquecendo as rígidas normas de conduta de seus países de origem, sujando-a, usando-a como lixeira e banheiro público, um lugar para

\footnotetext{
${ }^{9}$ Esse debate foi realizado no livro "A cidade no século XXI: segregação e banalização do espaço" (2011), tendo havido, em 2013, uma nova edição ampliada.
} 
gritar e fazer todo barulho que quiserem" (MONTANER, MUXÍ, 2011, p. 152).

Tudo isso contribui também para a saída de parte dos antigos residentes.

No Brasil, e mais explicitamente no Rio de Janeiro, incentivados pelo boom do mercado imobiliário e a promessa do aumento da sensação de segurança oferecida pela criação das Unidades de Polícia Pacificadora (UPP) ${ }^{10}$, empresários adquiriram imóveis em favelas cariocas para transformá-los em pousadas para turistas. Isso aconteceu de forma geral nas favelas da zona sul da cidade, mas na Favela do Vidigal o crescimento foi muito mais intenso.

Seguindo a posição de que é preciso complexificar os conceitos, há tempos já se afirma que a Favela do Vidigal passou por um processo de gentrificação. Entretanto, ali não foi necessário a ocorrência de investimentos em melhoria da infraestrutura física, a instalação de uma UPP em 2012 cumpriu importante papel. O discurso era que a "ocupação" permanente das favelas pela polícia diminuiria o controle territorial das facções ligadas ao tráfico de drogas e consequentemente a violência.

A mídia deu ampla divulgação ao projeto das UPPs, e associado a isso o Rio de Janeiro passava por um momento de inúmeros eventos internacionais, como a Copa do Mundo de Futebol (2014) e os Jogos Olímpicos (2016). Observou-se então, com o aumento da sensação de segurança, um aumento da procura por imóveis na Favela do Vidigal.

Houve um forte aumento no preço dos imóveis em toda a cidade, principalmente na zona sul, e na Favela do Vidigal não foi diferente. O preço dos aluguéis e dos imóveis aumentaram bastante, mas houve também forte elevação sobre os preços de bens e serviços dentro da favela. Além disso, novos moradores com um padrão de rendimentos mais elevado demandam bens e serviços de outro nível.

Os moradores do Vidigal comungam de uma vista deslumbrante da costa da cidade, o que contribuiu também para o investimento estrangeiro no local. Foram construídas várias pousadas e até um luxuoso exemplar - Mirante do Arvrão (Figuras 13 e 14) - no alto do morro com diárias ao custo de $\mathrm{R} \$ 330$. No site do hotel é possível descobrir que foi projetado pelo artista plástico brasileiro Hélio Pellegrino, além de construírem um discurso de sua importância para a economia local, mesmo sem deixar claro como.

\footnotetext{
${ }^{10}$ No Capítulo 3 da nossa obra intitulada "A cidade que queremos: produção do espaço e democracia" (2021) desenvolvemos um debate acerca da política de segurança.
} 


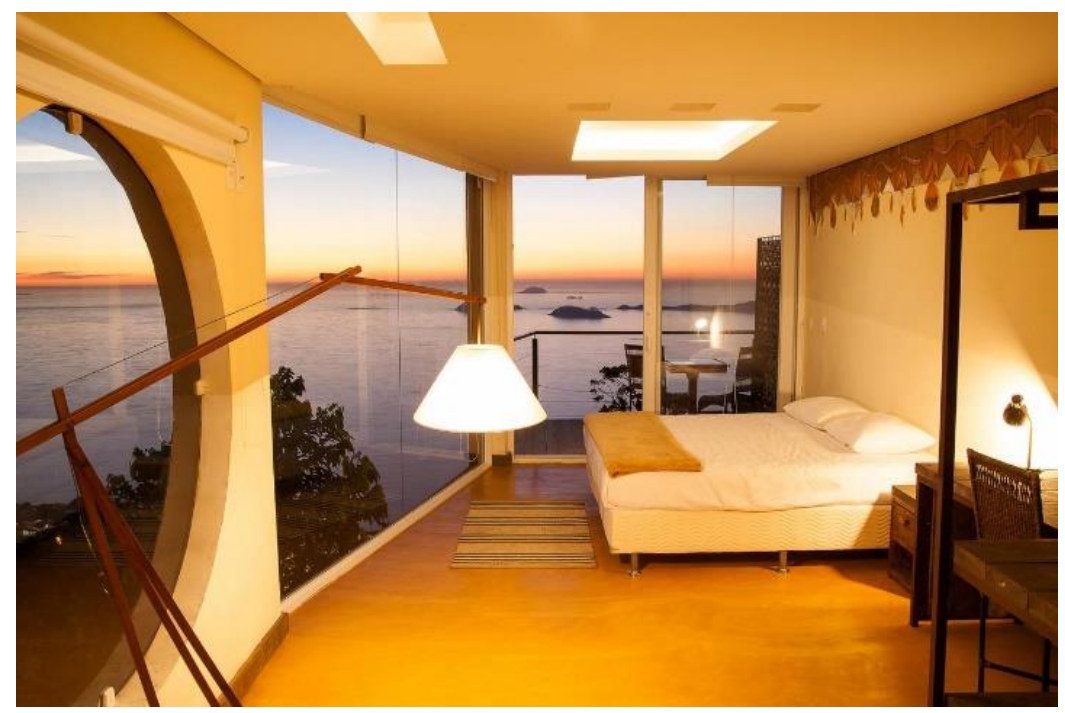

Figura 13: Pousada luxuosa na Favela do Vidigal.

Fonte: Booking (2020).

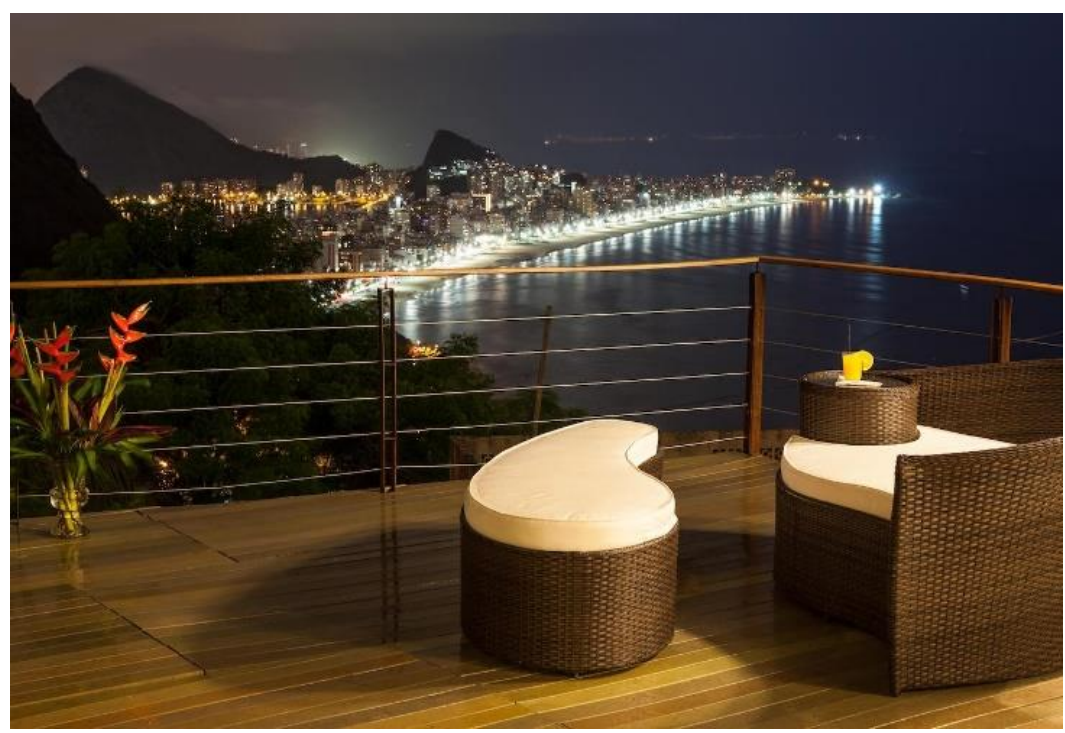

Figura 14: Varanda com vista panorâmica. Fonte: Booking (2020).

Apesar de haver relatos dos moradores afirmando que são proibidos de construir qualquer coisa no local, houve expansão de imóveis adicionando novos andares para alugar por temporada a turistas. 
Caminhando pelo Vidigal e ouvindo os moradores, há inúmeras histórias de vizinhos que tiveram de se mudar, pois não conseguiam mais arcar com os custos de permanência no local devido ao aumento dos aluguéis. Em outros casos, houve aqueles que eram proprietários e receberam "tão boas ofertas" pelos seus terrenos ou casas que acabaram vendendo-os. Nos dois casos os antigos moradores não conseguiram permanecer na Favela do Vidigal e acabaram se mudando para locais mais distantes.

As histórias da inviabilidade de permanência dos antigos moradores têm se repetido com tanta frequência, que as associações de moradores têm realizado reuniões com a comunidade para falar da gentrificação. Isso é importante e interessante, já que aqueles que estão vivenciando o problema o identificam como gentrificação (Figuras 15 e 16). E mais, apontam os malefícios trazidos pelo processo, elencando o que percebem como a característica fundamental da gentrificação: a espoliação.

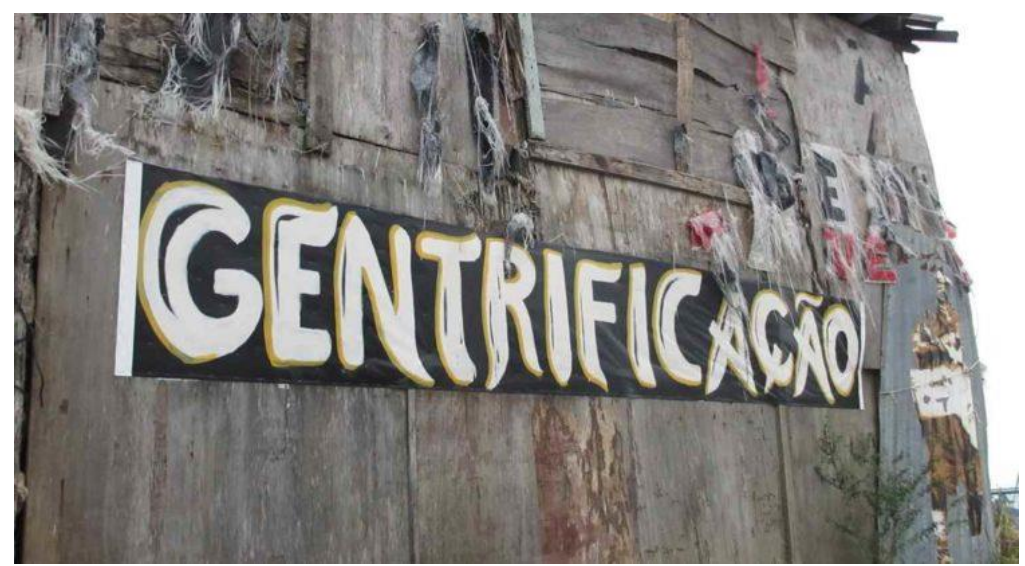

Figura 15: A própria população identifica o processo como gentrificação. Fonte: Combate Racismo Ambiental (2018).

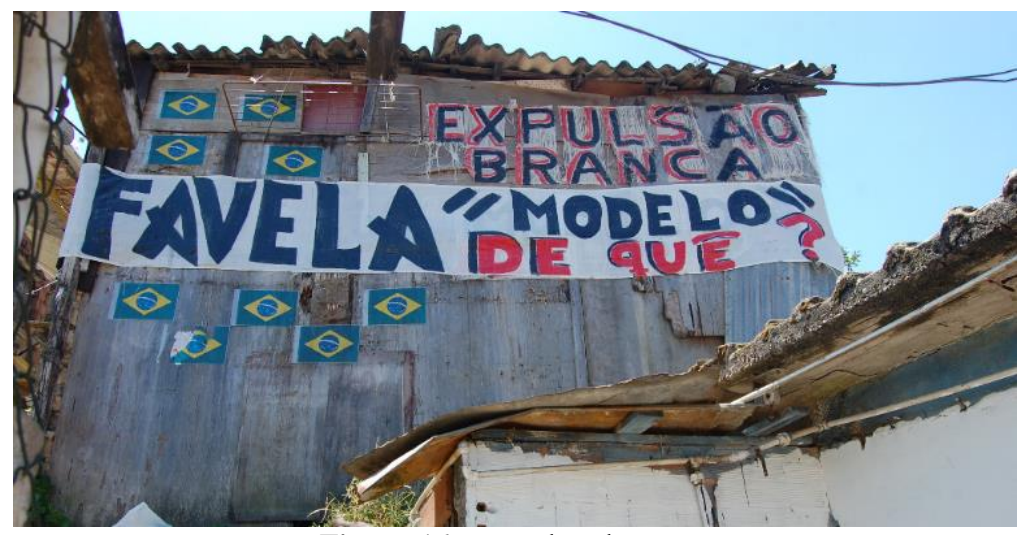

Figura 16: "Expulsão branca".

Fonte: Observatório das Metrópoles (2018). 
Se afirmamos que a expressão turistificação é uma forma característica de gentrificação, o mesmo poderíamos afirmar acerca da expressão estudantificação (studentification). Esta palavra - menos utilizada no Brasil - identificaria uma forma característica de gentrificação associada à abertura de universidades em determinados bairros das cidades. Tal expressão foi cunhada pelo geógrafo inglês Darren Smith (2005; 2006) para caracterizar uma forma específica de gentrificação em que os estudantes se tornam um fator determinante para as mudanças do tecido urbano. Outros autores (por exemplo, HUBBARD, 2008; NAKAZAWA, 2017; SMITH, HOLT, 2007) têm utilizado a partir de então essa denominação, afirmando que quando o entorno de uma instituição de ensino superior é ocupado por alunos e ocorrem mudanças nos âmbitos sociais, econômicos, físicos e culturais, esse processo deve ser entendido como estudantificação.

Como vimos defendendo neste artigo, preferimos apontar para uma maior abrangência e complexificação do conceito de gentrificação, visto que em sua essência, o caráter espoliativo é o ponto e o resultado fundamental do processo. Como afirmamos anteriormente, após o investimento em infraestrutura, em novas construções ou em um grande projeto de renovação urbana, há uma maior valorização de determinado lugar, fazendo com que os antigos moradores não consigam se manter ali devido ao encarecimento do custo de vida no local.

Como tentamos deixar claro, a demanda por novos moradores, com poder aquisitivo mais elevado e com ar mais jovem e moderno, trata-se de uma demanda criada e claramente planejada. Justamente por isso, autores como Vollmer (2018, p. 108) apontam para uma estratégia de política demográfica, e nesse caso, "a promoção da classe média como política demográfica se converte no eixo central da política urbana e da gentrificação promovida pelas administrações públicas". Em outras palavras, a autora acredita que o que denomina estratégia demográfica é uma política de população que pretende influenciar no tamanho e na estrutura da população.

Todavia essa política demográfica encontra-se oculta por trás, inclusive, de discursos de incentivo ao mix social. Ou seja, valorizando a ideia de mistura entre os diferentes estratos sociais nos bairros da cidade. Curiosamente tal discurso esconde a gentrificação, visto que defende o mix social apenas nos bairros que estão sendo afetados por esse processo. Os promotores imobiliários e os governantes em nenhum momento defendem ou promovem o mix social em bairros nobres ou de classe média alta. Ao fim e ao cabo, não nos resta dúvida, o discurso da importância do mix social é uma estratégia clara para ocultar a expulsão da população mais pobre dos bairros que passam por gentrificação.

Portanto e por tudo isso, a gentrificação não é um efeito colateral indesejado ou um fenômeno natural, é fruto de políticas públicas, de ações e omissões dos governos instituídos; e, obviamente, de sua associação aos interesses imobiliários e financeiros ${ }^{11}$.

\footnotetext{
${ }^{11}$ No capítulo 4 e nas Considerações Finais de nossa obra intitulada "A cidade que queremos: produção do espaço e democracia" (2021) retomamos esse debate com o intuito de apontar caminhos para escaparmos desse processo que representa tão forte injustiça espacial.
} 


\section{Referências}

ALVES, Sónia. Requalificação e gentrificação no Centro Histórico do Porto. Scripta Nova. Revista Electrónica de Geografía y Ciencias Sociales. Universidad de Barcelona, Vol. XXI, N. 557, 28 de febrero de 2017.

ATKINSON, Rowland, BRIDGE, Gary. Gentrification in a global perspective: the new urban colonialism. London: Routledge, 2005.

COMBATE RACISMO AMBIENTAL. Lei de Regularização Fundiária de Temer, um ano depois: avaliando o impacto nas favelas, 31 ago. 2018. Disponível em:

https://racismoambiental.net.br/2018/08/31/lei-de-regularizacao-fundiaria-de-temer-um-anodepois-avaliando-o-impacto-nas-favelas/ (acesso: 21/03/2021).

CRIEKINGEN, Mathieu Van. A cidade renasce! Formas, políticas e impactos da revitalização residencial em Bruxelas. In BIDU-ZACHARIA-SEN, Catherine. De volta à cidade: dos processos de gentrificação às políticas de "revitalização" dos centros urbanos. São Paulo: Annablume, 2007.

DIÁRIO DO PORTO. Porto Maravilha em crise: o futuro nas mãos da Caixa, 07 jun. 2018. Disponível em: https://diariodoporto.com.br/porto-maravilha-em-crise-o-futuro-nas-maos-dacaixa/ (acesso: 07/07/2018).

DINHEIRO VIVO. Centenas em manifestação em Lisboa: "Turistas não são habitantes", 24 mar. 2018. Disponível em: https://www.dinheirovivo.pt/economia/algumas-centenas-de-pessoasprotestam-contra-gestao-da-cidade-de-lisboa/ (acesso: 19/03/2021).

DOMESTIKA. Gentrificación y turistificación, 18 jul. 2018. Disponível em: https://www.domestika.org/es/projects/416003-gentrificacion-y-turistificacion (acesso: 22/03/2020).

ESQUERDA. Gentrificação: palavra suja do urbanismo austeritário, 8 out. 2016. Disponível em: https://www.esquerda.net/dossier/gentrificacao-palavra-suja-do-urbanismo-austeritario/44804 (acesso: 16/03/2020).

FERREIRA, Alvaro. A cidade que queremos: produção do espaço e democracia. Rio de Janeiro: Consequência, 2021.

FERREIRA, Alvaro. Produção do espaço, autogestão, comunidade e estado: provocações a partir de Karl Marx. GEOgraphia, v. 21, p. 48-57, 2019 b.

FERREIRA, Alvaro. A luta pela "verdadeira democracia" na produção do espaço: por outro projeto de sociedade. In FERREIRA, Alvaro, RUA, João, MATTOS, Regina Célia de (Orgs.). Produção do espaço. Rio de Janeiro: Consequência, 2019c, p. 23-54.

FERREIRA, Alvaro. Pela construção da verdadeira democracia: entre conselhos populares e ciberdemocracia. In ZAAR, Miriam, CAPEL, Horacio (Coords. y Eds.) Las ciencias sociales y la edificación de una sociedad post-capitalista. Barcelona: Universidad de Barcelona/Geocrítica, 2018 (http://www.ub.edu/geocrit/Sociedad-postcapitalista/Sociedad-postcapitalista.pdf). ISBN: 978-84-09-06079-5. 
FERREIRA, Alvaro. Produção alienadora das cidades e indícios de insurgência: materialização, substrução e projeção. In FERREIRA, Alvaro, RUA, João, MATTOS, Regina Célia de. O espaço e a metropolização: cotidiano e ação. Rio de Janeiro: Consequência, 2017, p. 91-120.

FERREIRA, Alvaro. Metropolização do espaço, tensões e resistências: entre espaços de controle e controle do espaço. Scripta Nova: Revista Electrónica de Geografía y Ciencias Sociales, Universidad de Barcelona, v. XVIII, n. 493 (55), 1 de nov. de 2014.

FERREIRA, Alvaro. A imagem virtual transformada em paisagem e o desejo de esconder as tensões no espaço: por que falar em atores, agentes e mobilizações? In: FERREIRA, Alvaro; RUA, João; MARAFON, Glaucio; SILVA, Augusto César Pinheiro da (Orgs.). Metropolização do espaço: gestão territorial e relações urbano-rurais. Rio de Janeiro: Consequência, 2013a. p. 5374.

FERREIRA, Alvaro. A cidade no século XXI: segregação e banalização do espaço. 2. ed. ampliada. Rio de Janeiro: Consequência, 2013b. 323p.

GEOATIVISMO. Contra o direito à cidade, 13 set. 2016. Disponível em: https://geoactivismo.org/geografiando/contra-el-derecho-a-la-ciudad/ (acesso: 03/01/2020).

GLASS, Ruth. London: Aspects of Change. London: Centre for Urban Studies, 1963.

HOLM, Andrej. Is it or not? The conceptualisation of gentrification and displacement and its political implications in the case of Berlin-Prenzlauer Berg. City 13/2-3, 2010, pp.312-324.

HUBBARD, Phil. Regulating the social impacts of studentification: a Loughborough case study. Environment and Planning A: Economy and Space, Volume 40 Issue 2, February, 2008.

IDEAL. Las calles del Albaicín se llenan de pintadas contra el turismo, 29 mai. 2019. Disponível em: https://www.ideal.es/granada/aparece-pintada-anonima-albaicin-granada-20190529190840nt.html (acesso: 18/03/2021).

LEFEBVRE, Henri. Espaço e política. Belo Horizonte: UFMG, 2008.

LEFEBVRE, Henri. La presencia y la ausencia: contribución a la teoría de las representaciones. México: FCE, 2006. 305p.

LEFEBVRE, Henri. The production of space. Oxford, UK: Blackwell, 1994.

LEFEBVRE, Henri. La production de l'espace. Paris: Anthropos, 1974.

LENCIONI, Sandra. Metropolização do espaço: processos e dinâmicas. In FERREIRA, Alvaro, RUA, João, MARAFON, Glaucio, SILVA, Augusto César Pinheiro da (org.) Metropolização do espaço: gestão territorial e relações urbano-rurais. Rio de Janeiro: Consequência, 2013. p. 17-34.

LENCIONI, Sandra. Reconhecendo metrópoles: sociedade e território. In SILVA, Catia Antonia da et al. Metrópole: governo, sociedade e território. Rio de Janeiro: DP\&A, 2006.

MARX, Karl, ENGELS, Friedrich. A ideologia alemã: crítica da mais recente filosofia alemã em seus representantes Feuerbach, B. Bauer e Stirner, e do socialismo alemão em seus diferentes profetas (1845-1846). São Paulo: Boitempo, 2007.

MARX, Karl. Crítica da filosofia do direito de Hegel. São Paulo: Boitempo, 2005. 
MENDES, Luís. Gentrificação turística em Lisboa: neoliberalismo, financeirização e urbanismo austeritário em tempos de pós-crise capitalista 2008-2009. Cad. Metrop., São Paulo, v. 19, n. 39, pp. 479-512, maio/ago 2017.

MONTANER, Josep María, MUXÍ, Zaida. Arquitectura y política: ensayos para mundos alternativos. Barcelona: Gustavo Gili, 2011.

NAKAZAWA, Takashi. Expanding the scope of studentification studies. Geography Compass, Volume11, Issue1, January, 2017, e12300.

OBSERVATÓRIO DAS METRÓPOLES. A “gentrificação periférica” das favelas no Rio de Janeiro, 24 jan. 2018. Disponível em: https://www.observatoriodasmetropoles.net.br/gentrificacaoperiferica-das-favelas-no-rio-de-janeiro/ (acesso: 23/03/2021).

OBSERVATORIO DEL TURISMO IRRESPONSABLE. Gentrificación en Barcelona, 02 jul. 2018. Disponível em: http://oti.turismo-sostenible.net/project/turismo-masivo-y-gentrificacion-enbarcelona/ (acesso: 13/03/2020).

OPERAÇÃO URBANA CONSORCIADA DA REGIÃO DO PORTO DO RIO. Caracterização do empreendimento, mar. 2012. Disponível em:

https://portomaravilha.com.br/conteudo/estudos/impacto-avizinhaca/III.\%20Caracterizacao\%20do\%20Empreendimento.pdf (acesso: 06/04/2012).

PEREIRA, Paulo Cesar Xavier. El vaciamiento de la noción de gentrificación y sus consecuencias para la lucha urbana y el direcho de la ciudad. In Anais Contested Cities: Congreso Internacional, Madrid 2016, ejo 4, artículo n. 4-522. http://contested-cities.net/working-papers/2016/elvaciamiento-de-la-nocion-de-gentrificacion-y-sus-consecuencias-para-la-lucha-urbana-y-elderecho-de-la-ciudad/

PÚBLICA. Engenharia financeira subvalorizou terrenos públicos no Porto Maravilha, 09 ago. 2016. Disponível em https://apublica.org/2016/08/engenharia-financeira-subvalorizou-terrenospublicos-no-porto-maravilha/ (acesso: 02/02/2020).

PÚBLICO. Tres pasos para controlar AirBnB, 01 jul. 2017. Disponível em: https://www.publico.es/sociedad/airbnb-tres-pasos-controlar-airbnb.html (acesso: 13/03/2020).

SABATÉ MURIEL, Irene. Epílogo. In VOLLMER, Lisa. Estrategias contra la gentrificación: por una ciudad desde abajo. Pamplona, Espanha: Katakrak Liburuak, 2019, p. 231-248.

SMITH, Darren, HOLT, Louise. Studentification and 'Apprentice' Gentrifiers within Britain's Provincial Towns and Cities: Extending the Meaning of Gentrification. Economy and space, Volume 39, Issue 1, January, 2007.

SMITH, Darren. Studentification and Moral Panic: when is a 'Student Area' a 'Student Ghetto'? The 3rd International Population Geographies Conference. United Kingdom: University of Liverpool, UK, $20^{\text {th }}$ June 2006.

SMITH, Darren. 'Studentification ication': the gentrification factory? In: ATKINSON, Rowland, BRIDGE, Gary (Ed.). Gentrification in a global context: the new urban colonialism. UK: Routledge, 2005, p 72-89. 
SMITH, Neil. Gentrification and the rent gap. Annals of the Association of American Geographers, v. 77, n. 3, 1987, pp. 462-465.

SMITH, Neil. Toward a theory of gentrification: a back to the city movement by capital not people. Journal of the American Planning Association, n. 45, 1979, pp. 538-548.

TURISMOLOGIA. Turismofobia em Barcelona, 14 ago. 2018. Disponível em: http://www.turismologia.paulamarchesan.com/2018/08/14/turismofobia/ (acesso: 02/12/2020).

VALENCIA PLAZA. ¿Turismofobia en Valencia? Un poquito de seriedad, 07 set. 2017. Disponível em: https://valenciaplaza.com/turismofobia-en-valencia-un-poquito-de-seriedad (acesso: 16/02/2021).

VOLLMER, Lisa. Estrategias contra la gentrificación: por una ciudad desde abajo. IruñeaPamplona, Espanha: Katakrak Liburuak, 2019.

VOLLMER, Lisa. Strategien gegen Gentrifizierung. Berlin: Schmetterling Verlag GmbH, 2018.

\begin{abstract}
Alvaro Ferreira
Doutor em Geografia Humana pela Universidade de São Paulo (USP), Mestre em Planejamento Urbano e Regional pelo Instituto de Pesquisa e Planejamento Urbano e Regional (IPPUR) da Universidade Federal do Rio de Janeiro (UFRJ) e graduado em Geografia pela Universidade do Estado do Rio de Janeiro (UERJ). Atualmente é professor do Departamento de Geografia e Meio Ambiente da Pontifícia Universidade Católica do Rio de Janeiro (PUC-Rio), onde também atua no Programa de Pós-Graduação em Geografia, e do Departamento de Geografia da FEBF-UERJ. Foi Professor Visitante Sênior da Universidad Autónoma de Madrid e Investigador Visitante do Instituto de Ciências Sociais (ICS) da Universidade de Lisboa. Pesquisador 1D do Conselho Nacional de Desenvolvimento Científico e Tecnológico (CNPq).

Rua Marquês de São Vicente, 225 - Gávea, Rio de Janeiro - RJ, 22451-900

Email: alvaro_ferreira@puc-rio.br

Email: alvaro.ferreira.geo@gmail.com
\end{abstract}

Recebido para publicação em novembro de 2020

Aprovado para publicação em fevereiro de 2021 